medRxiv preprint doi: https://doi.org/10.1101/2021.08.31.21262919; this version posted September 5, 2021. The copyright holder for this preprint

(which was not certified by peer review) is the author/funder, who has granted medRxiv a license to display the preprint in perpetuity.

This article is a US Government work. It is not subject to copyright under 17 USC 105 and is also made available for use under a CCO license.

\title{
Expected Rates of Select Adverse Events following Immunization for COVID-19 Vaccine Safety Monitoring
}

\author{
Winston E. Abara ${ }^{1}$, Julianne Gee ${ }^{1}$, Yi Mu ${ }^{1}$, Mark Deloray ${ }^{1}$, Tun Ye ${ }^{1}$, David K. Shay ${ }^{1}$, and Tom Shimabukuro ${ }^{1}$
}

${ }^{1}$ CDC COVID-19 Response Team, Centers for Disease Control and Prevention, Atlanta, Georgia

The findings and conclusions in this report are those of the authors and do not necessarily represent the official position of the Centers for Disease Control and Prevention (CDC). Authors do not declare any conflict of interests or funding sources.

\section{Abstract}

Background: Knowledge of expected rates of potential adverse events of special interest (AESI) that may occur coincidentally following COVID-19 vaccination is essential for vaccine safety surveillance and assessment. We calculated the expected rates of 21 potential AESI following COVID-19 vaccination among vaccinated persons within 1 day, 7 days, and 42 days of vaccination.

Methods: We used meta-analytic methods to estimate background rates of 21 medical conditions considered potential AESI and calculated expected rates of each potential AESI within 1 day, 7 days, and 42 days of vaccination.

Results: Background rates of three commonly monitored AESI, Guillain-Barre syndrome (GBS), myopericarditis, and all-cause deaths were 2.0 GBS cases/100,000 person-years, 1.3 myopericarditis cases/100,000 person-years, and 863.8 all-cause deaths/100,000 person-years, respectively. Based on these background rates, if $10,000,000$ persons are vaccinated, we would expect $0.5,3.7$, and 22.5 GBS cases; $0.3,2.4$, and 14.3 myopericarditis cases; and $236.5,1655.5$, and 9932.8 all-cause deaths to occur in coincident temporal association (i.e., as a result of background incidence) within 1 day, 7 days, and 42 days of vaccination, respectively.

Conclusion: Knowledge of expected rates of potential AESI can help contextualize adverse health events associated temporally with immunization, aid in safety signal detection, guide COVID-19 vaccine public health communication, and inform benefit-risk assessments of COVID-19 vaccines.

Keyword: Background rates; Expected rates; Adverse events; COVID-19; Vaccination; Vaccine safety; Surveillance 
medRxiv preprint doi: https://doi.org/10.1101/2021.08.31.21262919; this version posted September 5, 2021. The copyright holder for this preprint (which was not certified by peer review) is the author/funder, who has granted medRxiv a license to display the preprint in perpetuity.

This article is a US Government work. It is not subject to copyright under 17 USC 105 and is also made available for use under a CCO license.

\section{INTRODUCTION}

The World Health Organization declared a global pandemic of coronavirus disease 2019 (COVID-19) on March 11, 2020 (1). Since COVID-19 was first detected in the United States in January 2020, more than 38 million cases and 630,000 deaths have been reported as of August 30, 2021 (2). COVID-19 vaccines are a critical tool to control and prevent COVID-19 illness (3-5). As of August 2021, one COVID-19 vaccine has received approval from the U.S. Food and Drug Administration (FDA) and two COVID-19 vaccines have received emergency use authorization. These vaccines are effective at reducing infection risk and severity of COVID-19 disease (3-5). They were developed using novel vaccine platforms. Two vaccines use mRNA encapsulated in lipid nanoparticles and the other uses a nonreplicating adenovirus vector to trigger an immune antibody response (6). Since emergency use authorization of these vaccines, large-scale COVID-19 vaccination programs have been implemented in the United States with the goal of increasing availability of and accessibility to COVID-19 vaccines to achieve community immunity in the population (7). Given the unprecedented speed of COVID-19 vaccine development, the use of novel vaccine technology, and rapid large-scale national COVID-19 vaccination, it is reasonable that people may have concerns about vaccine safety (8).

Mild to moderate local or systematic reactions after COVID-19 vaccination are common; reports of anaphylaxis and other serious adverse events such as myocarditis, thrombosis with thrombocytopenia syndrome (TTS), or Guillain-Barré syndrome (GBS) have been rare (9-11). Although a close temporal association between vaccination and an adverse event does not establish that the vaccine caused the event, such temporally associated events may lead to greater concern than more remote events. Public concern about vaccine safety can contribute to vaccine hesitancy, result in vaccine misinformation, and adversely affect vaccine uptake (12). The U.S. COVID-19 vaccine safety program comprehensively monitors the safety of all authorized COVID-19 vaccines to assess if potential adverse events are vaccine-related and exceed the expected background rate (i.e., incidence rate observed in a given population in the absence of vaccination). This monitoring is vital to ensuring safe vaccines and to promote vaccine confidence among the public. 
medRxiv preprint doi: https://doi.org/10.1101/2021.08.31.21262919; this version posted September 5, 2021. The copyright holder for this preprint (which was not certified by peer review) is the author/funder, who has granted medRxiv a license to display the preprint in perpetuity. This article is a US Government work. It is not subject to copyright under 17 USC 105 and is also made available for use under a CCO license.

Knowledge of the expected rates of medical conditions that would occur coincidentally (i.e., as a result of background incidence) in the U.S. population aids COVID-19 vaccine safety surveillance efforts by providing a baseline to determine if observed rates of adverse events following vaccination exceed expected rates regardless of vaccination. This information can also guide COVID-19 vaccine safety communication to the public and inform benefit-risk analyses of COVID-19 vaccines. We estimated the background rates of 21 medical conditions considered potential adverse events of special interest (AESI) following COVID-19 vaccination and calculated the expected rates of each AESI that would coincidentally occur among vaccinated persons in the general population within 1 day, 7 days, and 42 days after vaccination due to chance alone.

\section{METHODS}

Manuscript selection and eligibility criteria for AESI

For this analysis, we used a list of medical conditions considered potential AESI following COVID-19 vaccination from Gubernot et al. (13) (Table 1). This list was compiled by vaccine safety experts from the Centers for Disease Control and Prevention (CDC) and FDA; medical conditions considered as AESI were selected based on general or historical vaccine safety monitoring outcomes (e.g., death and GBS) and theoretical concerns related to COVID-19 disease outcomes (e.g., myopericarditis). Gubernot and colleagues reviewed the literature and presented a summary of incidence rates of these AESI that may be used in the safety surveillance and assessment of COVID-19 vaccines (13).

We reviewed the articles identified in the paper by Gubernot et al. (13). We restricted eligible studies for this analysis to those that were published in English, described a systematic process for case identification, used established and widely accepted case definitions, and included cases identified from a well-enumerated U.S. population, and reported a denominator (person-years) and numerator (number of events). If the denominator was not available in the article, we used the reported incidence rate and numerator to estimate a denominator. We excluded published articles that focused only on specific sub-populations (e.g. based on age, sex, and ethnicity), reported incidence rates from a non-U.S. population, were published prior to 1970, or where the denominator and numerator were both missing. 
medRxiv preprint doi: https://doi.org/10.1101/2021.08.31.21262919; this version posted September 5, 2021. The copyright holder for this preprint (which was not certified by peer review) is the author/funder, who has granted medRxiv a license to display the preprint in perpetuity. This article is a US Government work. It is not subject to copyright under 17 USC 105 and is also made available for use under a CCO license.

Rates for all-cause mortality, mortality attributed to heart disease, and mortality attributed to cerebrovascular disease were obtained from the National Vital Statistics System (NVSS) (14). The mortality rate attributed to sudden cardiac death was obtained from the American Heart Association's Heart Diseases and Stroke Statistics 2020 update report (15). For each type of mortality event, we obtained general population rates and rates by age group and sex.

\section{Analysis}

We used meta-analytic methods to estimate pooled rates of potential AESI using incidence rates obtained from eligible incidence studies for each medical condition considered as an AESI after COVID-19 vaccination. We used the 'metarate' function in R package meta v. 4.15-1 to conduct a random effects model to estimate the pooled incidence rate and $95 \%$ confidence intervals $(95 \% \mathrm{Cl})$ for each AESI. The pooled incidence rate and $95 \% \mathrm{Cl}$ was used as the background rate for each AESI. For medical conditions where only one article met the eligibility criteria, we used the reported incidence rate and $95 \% \mathrm{Cl}$ as the background rate and $95 \% \mathrm{Cl}$ for that AESI. Because we obtained rates for all mortality events from one source, we used the reported mortality rate for each mortality event as the background rate.

\section{Calculating expected AESI rates}

Using the derived background rates, we calculated the number of expected AESI that would occur coincidentally (i.e., not vaccine-related but as a result of background incidence) in 10,000,000 vaccinated people in the general population within 1 day, 7 days, and 42 days after vaccination with a COVID-19 vaccine. These post-vaccination time intervals were selected because the initial symptoms of an AESI can occur within hours and up to 42 days after vaccination (16). To calculate the number of expected coincident AESI, we divided the background rate by 365.25 to obtain a daily rate and by 100,000 to obtain a daily incidence rate per person. Then, we calculated the product of the daily incidence rate per person for each AESI, the number of vaccinated people $(10,000,000)$, and the associated post-vaccination time interval ( 1 day, 7 days, or 42 days). For example, an AESI with a background rate of $1.87 / 100,000$ person-years would yield a daily incidence rate per person of 0.0000000512 . The product of the daily incident AESI rate per person (0.0000000512), the number of vaccinated 
medRxiv preprint doi: https://doi.org/10.1101/2021.08.31.21262919; this version posted September 5, 2021. The copyright holder for this preprint (which was not certified by peer review) is the author/funder, who has granted medRxiv a license to display the preprint in perpetuity.

This article is a US Government work. It is not subject to copyright under 17 USC 105 and is also made available for use under a CCO license.

people $(10,000,000)$, and the post-vaccination time interval (7 days in this case) is 3.58 . Thus, we would expect to observe 3.6 cases of the AESI to occur coincidentally in $10,000,000$ vaccinated people in the general population within 7 days of receiving a COVID-19 vaccine, assuming a background rate of 1.87/100,000 personyears. This analysis was exempt from CDC Institutional Review Board review. The authors do not report any funding for this analysis.

\section{RESULTS}

The calculated background rates and expected number of coincident AESI cases in 10,000,000 vaccinated persons in the general population within 1 day, 7 days, and 42 days after vaccination are summarized in the text below and in Table 2 for select AESI.

\section{Guillain-Barre Syndrome}

We estimated a background rate of 2.0/100,000 person-years after a meta-analysis of six incidence studies of Guillain-Barre syndrome (17-22). Based on this background rate, we estimated that we would expect 0.5 coincident cases in 10,000,000 vaccinated persons within 1 day of vaccination; 3.7 coincident cases in $10,000,000$ vaccinated persons within 7 days of vaccination; and 22.4 coincident cases in $10,000,000$ vaccinated persons within 42 days of vaccination.

\section{Multiple sclerosis}

A meta-analysis of three incidence studies of multiple sclerosis $(21,23,24)$ yielded a background rate of $8.9 / 100,000$ person-years. Assuming this background rate, we calculated that we would expect 2.4 coincident cases in 10,000,000 vaccinated persons within 1 day post-vaccination; 17.0 coincident cases in 10,000,000 vaccinated persons within 7 days post-vaccination; and 101.8 cases in 10,000,000 vaccinated persons within 42 days post-vaccination.

\section{Transverse myelitis}

We estimated a background rate of 1.8/100,000 person-years after a meta-analysis of two incidence studies of transverse myelitis $(21,25)$. Based on this background rate, we would expect 0.5 coincident cases in $10,000,000$ vaccinated persons within 1 day of vaccination. We would also expect 3.4 cases in 10,000,000 
medRxiv preprint doi: https://doi.org/10.1101/2021.08.31.21262919; this version posted September 5, 2021. The copyright holder for this preprint (which was not certified by peer review) is the author/funder, who has granted medRxiv a license to display the preprint in perpetuity. This article is a US Government work. It is not subject to copyright under 17 USC 105 and is also made available for use under a CCO license.

vaccinated persons within 7 days of vaccination and 20.1 cases in 10,000,000 vaccinated persons within 42 days of vaccination.

\section{Optic neuritis}

A meta-analysis of two incidence studies of optic neuritis $(26,27)$ yielded a background rate of 4.3/100,000 person-years. Based on this background rate, we estimated that we would expect 1.2 coincident cases in 10,000,000 vaccinated persons, 8.3 coincident cases in 10,000,000 vaccinated persons, and 49.8 coincident cases in 10,000,000 vaccinated persons within 1 day, 7 days, and 42 days of vaccination, respectively.

\section{Acute disseminated encephalomyelitis}

We estimated a background rate of 0.6/100,000 person-years for acute disseminated encephalomyelitis after a meta-analysis of two incidence studies $(28,29)$. Based on this background rate, we estimated that we would observe 0.2 coincident cases in 10,000,000 vaccinated persons, 1.1 coincident cases in 10,000,000 vaccinated persons, and 6.6 coincident cases in 10,000,000 vaccinated persons within 1 day, 7 days, and 42 days of vaccination, respectively.

\section{Aseptic meningitis}

Because only one incidence rate study of aseptic meningitis was eligible for this analysis (30), we used the reported incidence rate $(17.8 / 100,000$ person-years) in this study as the background rate. Therefore, we would expect to observe 4.9 coincident cases in 10,000,000 vaccinated persons within 1 day post-vaccination; 34.1 coincident cases in 10,000,000 vaccinated persons within 7 days post-vaccination; and 204.7 coincident cases in 10,000,000 vaccinated persons within 42 days post-vaccination based on this background rate.

\section{Encephalitis}

We used the incident rate $(3.4 / 100,000$ person-years) reported from one eligible study (30) as the background rate for encephalitis in this analysis. Assuming this background rate, we calculated that we would expect 0.9 coincident cases per 10,000,000 vaccinated persons within 1 day post-vaccination; 6.5 coincident cases per 10,000,000 vaccinated persons within 7 days post-vaccination; and 39.2 coincident cases per 10,000,000 vaccinated persons within 42 days post-vaccination. 
medRxiv preprint doi: https://doi.org/10.1101/2021.08.31.21262919; this version posted September 5, 2021. The copyright holder for this preprint (which was not certified by peer review) is the author/funder, who has granted medRxiv a license to display the preprint in perpetuity.

This article is a US Government work. It is not subject to copyright under 17 USC 105 and is also made available for use under a CCO license.

\section{Seizure disorders}

We categorized seizure disorders as first unprovoked seizure and epilepsy (recurrent unprovoked seizures). A meta-analysis of two incidence studies of first unprovoked seizures $(31,32)$ yielded a background rate of 53.3/100,000 person-years and a meta-analysis of two incidence studies of epilepsy $(31,32)$ yielded a background rate of $38.6 / 100,000$ person-years. Based on the background rate of first unprovoked seizures, we expect to observe 14.6 coincident cases in 10,000,000 vaccinated persons within 1 day post-vaccination; 102.1 coincident cases in 10,000,000 vaccinated persons within 7 days post-vaccination; and 612.6 coincident cases in 10,000,000 vaccinated persons within 42 days post-vaccination.

Based on the background rate for epilepsy, we would expect to observe 10.6 coincident cases in 10,000,000 vaccinated persons within 1 day post-vaccination; 73.9 coincident cases in 10,000,000 vaccinated persons within 7 days post-vaccination; and 443.4 coincident cases in 10,000,000 vaccinated persons within 42 days post-vaccination.

\section{Cerebrovascular accident (ischemic and hemorrhagic stroke)}

One study was eligible for this analysis and we used the reported incidence rate reported in this study (33) as the background rate for cerebrovascular accident (410.2/100,000 person-years). We would expect 112.3 coincident cases in 10,000,000 vaccinated people, 786.2 coincident cases in 10,000,000 vaccinated people, and 4717.1 coincident cases in 10,000,000 vaccinated people within 1 day, 7 days, and 42 days of vaccination.

\section{Narcolepsy}

The incidence rate from one study (34) was used as the background rate for narcolepsy $(1.4 / 100,000$ person-years). Based on this background rate, we estimated that we would expect 0.4 coincident cases in $10,000,000$ vaccinated people, 2.6 coincident cases in 10,000,000 vaccinated people, and 15.7 coincident cases in 10,000,000 vaccinated people to occur within 1 day, 7 days, and 42 days of vaccination, respectively.

\section{Pericarditis and myopericarditis}

We estimated a background rate of 7.6/100,000 person-years for pericarditis after a meta-analysis of two incidence studies $(35,36)$. At this background rate, we would expect to observe 2.1 coincident cases in 
medRxiv preprint doi: https://doi.org/10.1101/2021.08.31.21262919; this version posted September 5, 2021. The copyright holder for this preprint (which was not certified by peer review) is the author/funder, who has granted medRxiv a license to display the preprint in perpetuity. This article is a US Government work. It is not subject to copyright under 17 USC 105 and is also made available for use under a CCO license.

10,000,000 vaccinated persons within 1 day post-vaccination; 14.6 coincident cases in $10,000,000$ vaccinated persons within 7 days post-vaccination; and 86.8 coincident cases in 10,000,000 vaccinated persons within 42 days post-vaccination.

We used the incidence rate from one study (36) as the background rate for myopericarditis $(1.3 / 100,000$ person-years). At this background rate, we would expect to observe 0.3 coincident cases in 10,000,000 vaccinated persons within 1 day post-vaccination; 2.4 coincident cases in 10,000,000 vaccinated persons within 7 days post-vaccination; and 14.3 coincident cases in 10,000,000 vaccinated persons within 42 days postvaccination.

\section{Venous thromboembolism}

We estimated a background rate of $145.1 / 100,000$ person-years after a meta-analysis of two incidence studies of venous thromboembolism $(37,38)$. Given this background rate, 39.7 coincident cases in 10,000,000 vaccinated people would be expected to occur within 1 day of vaccination; 278.0 coincident cases in 10,000,000 vaccinated people would be expected to occur within 7 days of vaccination; and 1668.2 coincident cases in $10,000,000$ vaccinated people would be expected to occur within 42 days of vaccination.

\section{Acute myocardial infarction}

We used the incident rate (566.5/100,000 person-years) reported from one eligible study (15) as the background rate for acute myocardial infarction. Based on this background rate, we estimated that we would expect 155.1 coincident cases in 10,000,000 vaccinated people, 1085.8 coincident cases in 10,000,000 vaccinated people, and 6514.5 coincident cases in 10,000,000 vaccinated people to occur within 1 day, 7 days, and 42 days of vaccination, respectively.

\section{Pregnancy loss (gestational age $<20$ weeks), including early pregnancy loss and spontaneous abortion}

We estimated a background rate of 20054.9/100,000 person-years for pregnancy loss among pregnant persons (39-42). We would expect 5,490.7 cases in 10,000,000 vaccinated people within 1 day of vaccination as coincident cases based on this background rate. We would also expect 38,435.0 cases in 10,000,000 vaccinated 
medRxiv preprint doi: https://doi.org/10.1101/2021.08.31.21262919; this version posted September 5, 2021. The copyright holder for this preprint (which was not certified by peer review) is the author/funder, who has granted medRxiv a license to display the preprint in perpetuity. This article is a US Government work. It is not subject to copyright under 17 USC 105 and is also made available for use under a CCO license.

people within 7 days of vaccination and $230,610.1$ cases in 10,000,000 vaccinated people within 42 days of vaccination as coincident cases.

\section{Fetal death (fetal death occurring after 20 weeks gestation)}

We estimated a background rate of 569.8/100,000 person-years of fetal death among pregnant persons after a meta-analysis of three studies of fetal death (43-45). We estimated that 156.0 coincident cases in 10,000,000 vaccinated people would occur within 1 day of vaccination; 1,092.0 coincident cases in 10,000,000 vaccinated people would occur within 7 days of vaccination; and 6,552.2 cases in 10,000,000 vaccinated people would occur within 42 days of vaccination assuming this background rate.

\section{Mortality events}

The background rates and number of expected coincident deaths attributed to all causes, heart disease, cerebrovascular disease, and sudden cardiac events overall, and by age group and gender are summarized in the text below and in Table 3 .

\section{All-cause deaths}

We used all-cause mortality rate from NVSS (14) as the background rate for all-cause deaths (863.8/100,000 persons). We estimated that we would expect 236.5 coincident all-cause deaths in 10,000,000 vaccinated people within 1 day of vaccination; 1,655.5 coincident all-cause deaths in 10,000,000 vaccinated people within 7 days of vaccination; and 9,932.8 coincident all-cause deaths in 10,000,000 vaccinated people within 42 days of vaccination. The number of expected coincident all-cause deaths in 10,000,000 vaccinated people in the general population within 1 day, 7 days, and 42 days of vaccination increased progressively by age and was consistently higher in males than in females.

\section{Deaths attributed to heart disease}

Using heart disease mortality rate from NVSS (14) as the background rate for deaths attributed to heart disease (198.8/100,000 persons) for this analysis, we estimated that we would expect 54.4 coincident deaths attributed to heart disease among 10,000,000 vaccinated people within 1 day of vaccination; 381.0 coincident deaths attributed to heart disease among 10,000,000 vaccinated people within 7 days of vaccination; and 
medRxiv preprint doi: https://doi.org/10.1101/2021.08.31.21262919; this version posted September 5, 2021. The copyright holder for this preprint (which was not certified by peer review) is the author/funder, who has granted medRxiv a license to display the preprint in perpetuity. This article is a US Government work. It is not subject to copyright under 17 USC 105 and is also made available for use under a CCO license.

2,286.0 coincident deaths attributed to heart disease among 10,000,000 vaccinated people within 42 days of vaccination. The number of expected coincident deaths attributed to heart disease in $10,000,000$ vaccinated people in the general population within 1 day, 7 days, and 42 days of vaccination increased progressively by age and was consistently higher in males than in females.

\section{Deaths attributed to cerebrovascular disease}

We used cerebrovascular disease mortality rate from NVSS (14) as the background rate for deaths attributed to cerebrovascular disease (44.9/100,000 persons) for this analysis. Assuming this background rate, we expected to observe 12.3 coincident cerebrovascular disease deaths among 10,000,000 vaccinated people within 1 day of vaccination; 86.1 coincident cerebrovascular deaths among 10,000,000 vaccinated people within 7 days of vaccination; and 516.3 coincident cerebrovascular deaths among 10,000,000 vaccinated people within 42 days of vaccination. The number of expected coincident deaths attributed to cerebrovascular disease in 10,000,000 vaccinated people in the general population within 1 day, 7 days, and 42 days of vaccination increased progressively by age and was higher in females than males.

\section{Sudden cardiac deaths}

We used the mortality rate attributed to sudden cardiac events $(97.1 / 100,000$ persons) from Virani et al. (15) as the background rate. Based on this background rate, we estimated that we would observe 26.6 coincident sudden cardiac deaths in 10,000,000 vaccinated people within 1 day of vaccination; 186.1 sudden cardiac deaths in 10,000,000 vaccinated people within 7 days of vaccination; and 1,116.6 coincident sudden cardiac deaths in 10,000,000 vaccinated people within 42 days of vaccination. The number of expected coincident deaths attributed to sudden cardiac events in 10,000,000 vaccinated people in the general population within 1 day, 7 days, and 42 days of vaccination increased progressively by age and was consistently higher in males than in females.

\section{DISCUSSION}

Our analyses estimate expected rates of select medical conditions considered potential AESI that may occur among vaccinated persons in the general population within 1 day, 7 days, and 42 days of COVID-19 
medRxiv preprint doi: https://doi.org/10.1101/2021.08.31.21262919; this version posted September 5, 2021. The copyright holder for this preprint (which was not certified by peer review) is the author/funder, who has granted medRxiv a license to display the preprint in perpetuity. This article is a US Government work. It is not subject to copyright under 17 USC 105 and is also made available for use under a CCO license.

vaccination. These estimates are important for post-authorization safety monitoring of COVID-19 vaccination and for evaluating temporally associated adverse events, for framing COVID-19 vaccine safety messages more precisely, for promoting public confidence in vaccination, and for conducting benefit-risk assessment of COVID19 vaccines.

Knowledge of expected rates of these medical conditions occurring in the general population is useful for evaluating COVID-19 vaccine safety $(12,13,46)$. The observed rates of these medical conditions following vaccination can be compared to the rates that would be expected to occur coincidentally among vaccinated persons in the general population regardless of COVID-19 vaccination. This comparison can help distinguish potential vaccine-related AESI from coincidental occurrences of these adverse health events in vaccinated persons $(12,46,47)$ and also complement clinical investigations by the CDC and FDA to understand the etiology of reports of potential AESI in vaccinated persons.

Expected rates of these medical outcomes in the general population can also inform public health communication about the safety of a COVID-19 vaccine $(12,13)$. Public confidence in vaccine safety can be negatively affected by reports that suggest a link between COVID-19 vaccination and adverse events (12). Spurious associations between vaccination and adverse health events can undermine vaccine acceptance and uptake and present challenges to achieving community immunity that is necessary for population-level protection (12). Communicating COVID-19 vaccine safety information to the public that explains that the observed rate of a potential AESI in the vaccinated population is not greater than expected can help the public understand that these events are coincident occurrences and unrelated to the vaccination (12). Framing vaccine safety communication this way may assuage vaccine safety concerns $(12,47)$.

Knowledge of expected rates of a potential AESI can also be useful when conducting a benefit-risk assessment of a specific COVID-19 vaccine. For example, the number of a potential AESI that is expected to occur among 10,000,000 million vaccinated persons can be compared to outcome benefits of interest such as the number of COVID-19 cases, hospitalizations, intensive care unit admissions, and deaths prevented per 
medRxiv preprint doi: https://doi.org/10.1101/2021.08.31.21262919; this version posted September 5, 2021. The copyright holder for this preprint (which was not certified by peer review) is the author/funder, who has granted medRxiv a license to display the preprint in perpetuity.

This article is a US Government work. It is not subject to copyright under 17 USC 105 and is also made available for use under a CCO license.

$10,000,000$ vaccinated persons. These comparisons can assess if the population- or individual-level benefit of a specific COVID-19 vaccine outweighs the risk of a potential AESI occurring in vaccinated persons.

There are limitations to this analysis. We only calculated expected rates for a limited set of medical conditions considered as potential AESI based on the list developed by Gubernot and colleagues (13). This list does not represent the full spectrum of potential vaccine safety outcomes of concern. The generalizability of the expected rates of some potential AESI in this paper to certain subpopulations (e.g., by age, sex, and race/ethnicity) is limited because of lack of data and because rates of potential AESI can vary substantially, especially by age. We calculated expected rates of potential AESI based on background rates obtained from incidence studies, thus, there may be residual or confounding biases in the studies that we could not adequately control. The expected rates of AESI presented here are based on U.S. studies and may not be applicable to nonU.S. populations. At the time of this analysis, there were no published papers available that report the incidence estimates of TTS and myocarditis, AESI that have been associated with COVID-19 vaccination. We were therefore unable to calculate their background and expected rates.

In conclusion, knowledge of expected rates of potential AESI in vaccinated persons in the general population is vital to COVID-19 vaccine safety monitoring, distinguishing vaccine-related events from coincident events that are temporally associated with but unrelated to vaccination, informing public health COVID-19 vaccine safety communication, promoting public confidence in the vaccine, and conducting specific COVID-19 vaccine benefit-risk assessment. 
medRxiv preprint doi: https://doi.org/10.1101/2021.08.31.21262919; this version posted September 5, 2021. The copyright holder for this preprint (which was not certified by peer review) is the author/funder, who has granted medRxiv a license to display the preprint in perpetuity.

This article is a US Government work. It is not subject to copyright under 17 USC 105 and is also made available for use under a CCO license.

Table 1. Conditions considered as potential adverse events of special interest after COVID-19 vaccination

\begin{tabular}{|l|l|l|}
\hline Condition & $\begin{array}{l}\text { Number of eligible } \\
\text { studies/reports included }\end{array}$ & Citations $^{1}$ \\
\hline Neurologic conditions & & \\
\hline Guillain-Barré syndrome & 6 & $(17-22)$ \\
\hline Multiple sclerosis & 3 & $(21,23,24)$ \\
\hline Transverse myelitis & 2 & $(21,25)$ \\
\hline Optic neuritis & 2 & $(26,27)$ \\
\hline Acute disseminated encephalomyelitis & 2 & $(28,29)$ \\
\hline Meningitis, aseptic & 1 & $(30)$ \\
\hline Encephalitis & 1 & $(30)$ \\
\hline Seizures (first unprovoked and epilepsy) & 2 & $(31,32)$ \\
\hline $\begin{array}{l}\text { Cerebrovascular accident (stroke), } \\
\text { ischemic and hemorrhagic }\end{array}$ & 1 & $(33)$ \\
\hline Narcolepsy & 1 & $(34)$ \\
\hline Cardiovascular conditions & & \\
\hline Myopericarditis and pericarditis & 2 & $(35,36)$ \\
\hline Venous thromboembolism & 2 & $(37,38)$ \\
\hline Acute myocardial infarction & 1 & $(15)$ \\
\hline Pregnancy-related conditions & & \\
\hline $\begin{array}{l}\text { Pregnancy loss (gestational age <20 weeks), } \\
\text { including early pregnancy loss and spontaneous abortion }\end{array}$ & 4 & $(39-42)$ \\
\hline Fetal deaths (gestational age $\geq 20$ weeks) & 3 & $(43-45)$ \\
\hline Mortality & 1 & $(14)$ \\
\hline All-cause & 1 & $(14)$ \\
\hline Heart disease & 1 & $(15)$ \\
\hline Cerebrovascular disease & 1 & \\
\hline Sudden cardiac death & 1 & \\
\hline Restricted to studies published in English, described asystematc process & \\
\hline
\end{tabular}

${ }^{1}$ Restricted to studies published in English, described a systematic process for case identification, used established and widely accepted case definitions, included cases identified from a well-enumerated U.S. population, and reported a denominator (person-years) and numerator (number of events). Studies that focused only on specific sub-populations (e.g., based on age, sex, and ethnicity), reported incidence rates from a non-U.S. population, were published prior to 1970, or where the denominator and numerator were both missing were excluded. 
Table 2. Background rates and expected rates for select adverse events of special interest (number of cases/10,000,000 vaccinated people)

\begin{tabular}{|c|c|c|c|c|}
\hline $\begin{array}{l}\text { Adverse event of special } \\
\text { interest }\end{array}$ & $\begin{array}{l}\text { Estimated background rate } \\
\text { (95\% confidence interval) }\end{array}$ & $\begin{array}{l}\text { Expected coincident cases } \\
\text { within } 1 \text { day of vaccination } \\
\text { (95\% confidence interval) }\end{array}$ & $\begin{array}{l}\text { Expected coincident cases } \\
\text { within } 7 \text { days of vaccination } \\
\text { (95\% confidence interval) }\end{array}$ & $\begin{array}{l}\text { Expected coincident cases } \\
\text { within } 42 \text { days of vaccination } \\
\text { (95\% confidence interval) }\end{array}$ \\
\hline Guillain-Barre syndrome & $2.0(1.4-2.6)$ & $0.5(0.4-0.7)$ & $3.7(2.6-4.9)$ & $22.4(15.5-29.4)$ \\
\hline Multiple sclerosis & $8.9(3.1-14.6)$ & $2.4(0.9-4.0)$ & $17.0(6.00-28.0)$ & $101.8(35.7-168.0)$ \\
\hline Transverse myelitis & $1.8(0.0-4.3)$ & $0.5(0.0-1.2)$ & $3.4(0.0-8.2)$ & $20.1(0.0-49.4)$ \\
\hline Optic neuritis & $4.3(3.3-5.3)$ & $1.2(0.9-1.5)$ & $8.3(6.3-10.2)$ & $49.8(38.1-61.4)$ \\
\hline $\begin{array}{l}\text { Acute disseminated } \\
\text { encephalomyelitis }\end{array}$ & $0.6(0.5-0.7)$ & $0.2(0.1-0.2)$ & $1.1(0.9-1.3)$ & $6.6(5.5-7.6)$ \\
\hline Aseptic Meningitis & $17.8(14.3-21.3)$ & $4.9(3.9-5.8)$ & $34.1(27.6-40.8)$ & $204.7(164.8-244.6)$ \\
\hline Encephalitis & $3.4(2.8-4.1)$ & $0.9(0.8-1.1)$ & $6.5(5.3-7.8)$ & $39.2(31.6-46.9)$ \\
\hline $1^{\text {st }}$ unprovoked seizure & $53.3(39.0-67.6)$ & $14.6(10.7-18.5)$ & $102.1(74.8-129.5)$ & $612.6(448.5-776.7)$ \\
\hline $\begin{array}{l}\text { Epilepsy (recurrent } \\
\text { unprovoked seizures) }\end{array}$ & $38.6(27.6-49.5)$ & $10.6(7.6-13.6)$ & $73.9(52.9-94.9)$ & $443.4(317.7-569.2)$ \\
\hline $\begin{array}{l}\text { Cerebrovascular accident } \\
\text { (stroke), ischemic and } \\
\text { hemorrhagic }\end{array}$ & $410.2(388.3-432.2)$ & $112.3(106.3-118.3)$ & $786.2(744.1-828.3)$ & 4717.1 (4464.5-4969.7) \\
\hline Narcolepsy & $1.4(0.9-1.8)$ & $0.4(0.3-0.5)$ & $2.6(1.8-3.5)$ & $15.7(10.5-20.9)$ \\
\hline Pericarditis & $7.6(3.7-11.4)$ & $2.1(1.0-3.1)$ & $14.6(7.0-21.9)$ & $86.8(42.2-131.4)$ \\
\hline Myopericarditis & $1.3(0.4-2.1)$ & $0.3(0.1-0.6)$ & $2.4(0.8-4.0)$ & $14.3(5.0-23.7)$ \\
\hline Venous thromboembolism & $145.1(138.3-151.9)$ & $39.7(7.9-41.6)$ & $278.0(265.0-291.1)$ & $1668.2(1589.9-1746.5)$ \\
\hline Myocardial infarction, acute & $566.5(565.3-567.8)$ & $155.1(154.8-155.7)$ & 1085.8 (1083.5-1088.1) & $6514.5(6500.3-6528.8)$ \\
\hline $\begin{array}{l}\text { Pregnancy loss (gestational } \\
\text { age }<20 \text { weeks), including } \\
\text { early pregnancy loss and } \\
\text { spontaneous abortion }\end{array}$ & 20054.9 (17485.8-22623.9) & 5490.7 (4787.4-6194.1) & $38435.0(33511.5-43358.6)$ & $230610.1(201068.9-260151.4)$ \\
\hline $\begin{array}{l}\text { Fetal death (fetal death } \\
\text { occurring after } 20 \text { weeks } \\
\text { gestation) }\end{array}$ & $569.8(542.6-597.1)$ & $156.0(148.6-163.5)$ & $1092.0(1039.8-1144.3)$ & $6552.2(6238.9-6865.5)$ \\
\hline
\end{tabular}


Table 3. Background rates and expected rates for select mortality events

\begin{tabular}{|c|c|c|c|c|c|c|}
\hline Mortality event & Sex & $\begin{array}{l}\text { Age group } \\
\text { (years) }\end{array}$ & $\begin{array}{l}\text { Background rate } \\
\text { (per } 100,000 \text { persons) }\end{array}$ & $\begin{array}{l}\text { Expected rates within } 1 \text { day } \\
\text { of vaccination } \\
\text { (per } 10,000,000 \text { vaccinated } \\
\text { persons) }\end{array}$ & $\begin{array}{l}\text { Expected rates within } 7 \text { days } \\
\text { of vaccination } \\
\text { (per } 10,000,000 \text { vaccinated } \\
\text { persons) }\end{array}$ & $\begin{array}{l}\text { Expected rates within } \\
42 \text { days of vaccination } \\
\text { (per } 10,000,000 \\
\text { vaccinated persons) }\end{array}$ \\
\hline \multirow{33}{*}{ All-cause deaths } & \multirow{11}{*}{ All } & $1-4$ & 24.3 & 6.7 & 12.8 & 279.4 \\
\hline & & $5-14$ & 13.6 & 3.7 & 26.1 & 156.4 \\
\hline & & $15-24$ & 74.0 & 20.3 & 141.8 & 850.9 \\
\hline & & $25-34$ & 132.8 & 36.4 & 254.5 & 1527.1 \\
\hline & & $35-44$ & 195.2 & 53.4 & 374.1 & 2244.6 \\
\hline & & $45-54$ & 401.5 & 109.9 & 769.5 & 4616.8 \\
\hline & & $55-64$ & 885.8 & 242.5 & 1697.6 & 10185.8 \\
\hline & & $65-74$ & 1790.9 & 490.3 & 3432.3 & 20593.5 \\
\hline & & $75-84$ & 4472.6 & 1224.5 & 8571.7 & 51430.3 \\
\hline & & $\geq 85$ & 13573.6 & 3716.3 & 26013.7 & 156082.5 \\
\hline & & Total & 863.8 & 236.5 & 1655.5 & 9932.8 \\
\hline & \multirow{11}{*}{ Male } & $1-4$ & 27.3 & 7.5 & 52.3 & 313.9 \\
\hline & & $5-14$ & 15.6 & 4.3 & 29.9 & 179.4 \\
\hline & & $15-24$ & 106.1 & 29.1 & 203.3 & 1220.0 \\
\hline & & $25-34$ & 183.3 & 50.2 & 351.3 & 2107.8 \\
\hline & & $35-44$ & 249.4 & 68.3 & 477.9 & 2867.8 \\
\hline & & $45-54$ & 496.5 & 135.9 & 951.5 & 5709.2 \\
\hline & & $55-64$ & 1112.3 & 304.5 & 2131.7 & 12790.3 \\
\hline & & $65-74$ & 2190.2 & 599.6 & 4197.5 & 25185.1 \\
\hline & & $75-84$ & 5254.0 & 1438.5 & 10069.3 & 60415.6 \\
\hline & & $\geq 85$ & 14689.2 & 4021.7 & 28151.8 & 168910.7 \\
\hline & & Total & 897.2 & 245.6 & 1719.5 & 10316.9 \\
\hline & \multirow{11}{*}{ Female } & $1-4$ & 21.1 & 5.8 & 40.4 & 242.6 \\
\hline & & $5-14$ & 11.4 & 3.1 & 21.9 & 131.1 \\
\hline & & $15-24$ & 40.4 & 11.1 & 77.4 & 464.6 \\
\hline & & $25-34$ & 80.8 & 22.1 & 154.9 & 929.1 \\
\hline & & $35-44$ & 141.4 & 38.7 & 271.0 & 1626.0 \\
\hline & & $45-54$ & 309.0 & 84.6 & 592.2 & 3553.2 \\
\hline & & $55-64$ & 674.7 & 184.7 & 1293.1 & 7758.4 \\
\hline & & $65-74$ & 1440.4 & 394.4 & 2760.5 & 16563.1 \\
\hline & & $75-84$ & 3869.1 & 1059.3 & 7415.1 & 44490.7 \\
\hline & & $\geq 85$ & 12966.5 & 3550.0 & 24850.2 & 149101.4 \\
\hline & & Total & 831.4 & 227.6 & 1593.4 & 9560.3 \\
\hline
\end{tabular}




\begin{tabular}{|c|c|c|c|c|c|c|}
\hline \multirow{33}{*}{$\begin{array}{l}\text { Deaths caused by } \\
\text { diseases of the } \\
\text { heart (ICD10 } \\
\text { codes I00이여, } \\
|11,| 13, \mid 20 \text { ? } \mid 51)\end{array}$} & \multirow{11}{*}{ All } & $1-4$ & 0.8 & 0.2 & 1.5 & 9.2 \\
\hline & & $5-14$ & 0.4 & 0.1 & 0.8 & 4.6 \\
\hline & & $15-24$ & 2.1 & 0.6 & 4.0 & 24.2 \\
\hline & & $25-34$ & 8.1 & 2.2 & 15.5 & 93.1 \\
\hline & & $35-44$ & 25.4 & 7.0 & 48.7 & 292.1 \\
\hline & & $45-54$ & 77.1 & 21.1 & 147.8 & 886.6 \\
\hline & & \begin{tabular}{|l|}
$55-64$ \\
\end{tabular} & 190.7 & 52.2 & 365.5 & 2192.9 \\
\hline & & 65-74 & 392.9 & 107.6 & 753.0 & 4517.9 \\
\hline & & \begin{tabular}{|l|}
$75-84$ \\
\end{tabular} & 1028.4 & 281.6 & 1970.9 & 11825.5 \\
\hline & & $\geq 85$ & 3882.9 & 1063.1 & 7441.6 & 44649.4 \\
\hline & & Total & 198.8 & 54.4 & 381.0 & 2286.0 \\
\hline & \multirow{11}{*}{ Male } & 1回4 & 0.8 & 0.2 & 1.5 & 9.2 \\
\hline & & $5-14$ & 0.5 & 0.2 & 0.9 & 5.8 \\
\hline & & $15-24$ & 2.8 & 0.8 & 5.4 & 32.20 \\
\hline & & $25-34$ & 10.7 & 2.9 & 20.5 & 123.0 \\
\hline & & $35-44$ & 34.7 & 9.5 & 66.5 & 399.0 \\
\hline & & \begin{tabular}{|l|}
$45-54$ \\
\end{tabular} & 109.1 & 29.9 & 209.1 & 1254.5 \\
\hline & & 55-64 & 273.2 & 74.8 & 523.6 & 3141.5 \\
\hline & & $65-74$ & 538.5 & 147.4 & 1032.0 & 6192.2 \\
\hline & & $75-84$ & 1306.8 & 357.8 & 2504.5 & 15026.9 \\
\hline & & $\geq 85$ & 4421.1 & 1210.4 & 8473.0 & 50838.1 \\
\hline & & Total & 216.9 & 59.4 & 415.7 & 2494.1 \\
\hline & \multirow{11}{*}{ Female } & $1-4$ & 0.8 & 0.2 & 1.5 & 9.2 \\
\hline & & $5-14$ & 0.4 & 0.1 & 0.8 & 4.6 \\
\hline & & $15-24$ & 1.4 & 0.4 & 2.7 & 16.1 \\
\hline & & $25-34$ & 5.5 & 1.5 & 10.5 & 63.2 \\
\hline & & $35-44$ & 16.2 & 4.4 & 31.1 & 186.3 \\
\hline & & $45-54$ & 45.9 & 12.6 & 88.0 & 527.8 \\
\hline & & $55-64$ & 113.9 & 31.2 & 218.3 & 1309.7 \\
\hline & & $65-74$ & 265.1 & 72.6 & 508.1 & 3048.4 \\
\hline & & $75-84$ & 813.5 & 222.7 & 1559.1 & 9354.4 \\
\hline & & $\geq 85$ & 3589.9 & 982.9 & 6880.0 & 41280.2 \\
\hline & & Total & 181.2 & 49.6 & 347.3 & 2083.6 \\
\hline \multirow{5}{*}{$\begin{array}{l}\text { Deaths caused by } \\
\text { cerebrovascular } \\
\text { diseases (ICD10 } \\
\text { codes I60미영 }\end{array}$} & \multirow{5}{*}{ All } & $1-4$ & 0.4 & 0.1 & 0.8 & 4.6 \\
\hline & & $5-14$ & 0.2 & 0.1 & 0.4 & 2.3 \\
\hline & & $15-24$ & 0.4 & 0.1 & 0.8 & 4.6 \\
\hline & & $25-34$ & 1.3 & 0.4 & 2.5 & 15.0 \\
\hline & & $35-44$ & 4.4 & 1.2 & 8.4 & 50.6 \\
\hline
\end{tabular}




\begin{tabular}{|c|c|c|c|c|c|c|}
\hline \multirow{28}{*}{$\begin{array}{l}\text { Deaths caused by } \\
\text { cerebrovascular } \\
\text { diseases (ICD10 } \\
\text { codes I60?169) }\end{array}$} & & $45-54$ & 12.3 & 3.4 & 23.6 & 141.4 \\
\hline & & $55-64$ & 30.3 & 8.3 & 58.1 & 348.4 \\
\hline & & $65-74$ & 76.4 & 20.9 & 146.4 & 878.5 \\
\hline & & $75-84$ & 263.1 & 72.0 & 504.2 & 3025.3 \\
\hline & & $\geq 85$ & 993.5 & 272.0 & 1904.1 & 11424.2 \\
\hline & & Total & 44.9 & 12.3 & 86.1 & 516.3 \\
\hline & \multirow{11}{*}{ Male } & $1-4$ & 0.5 & 0.2 & 1.0 & 5.8 \\
\hline & & $5-14$ & 0.3 & 0.1 & 0.6 & 3.5 \\
\hline & & $15-24$ & 0.4 & 0.1 & 0.8 & 4.6 \\
\hline & & $25-34$ & 1.5 & 0.4 & 2.9 & 17.3 \\
\hline & & $35-44$ & 5.1 & 1.4 & 9.8 & 58.6 \\
\hline & & $45-54$ & 14.4 & 3.9 & 27.6 & 165.6 \\
\hline & & $55-64$ & 36.2 & 9.9 & 69.4 & 416.3 \\
\hline & & $65-74$ & 86.7 & 23.7 & 166.2 & 997.0 \\
\hline & & $75-84$ & 273.5 & 74.9 & 524.2 & 3145.0 \\
\hline & & $\geq 85$ & 883.3 & 241.8 & 1692.8 & 10157.1 \\
\hline & & Total & 38.4 & 10.5 & 73.6 & 441.6 \\
\hline & \multirow{11}{*}{ Female } & $1-4$ & 0.3 & 0.1 & 0.6 & 3.5 \\
\hline & & $5-14$ & 0.2 & 0.1 & 0.4 & 2.3 \\
\hline & & $15-24$ & 0.3 & 0.1 & 0.6 & 3.5 \\
\hline & & $25-34$ & 1.1 & 0.3 & 2.1 & 12.7 \\
\hline & & $35-44$ & 3.8 & 1.0 & 7.3 & 43.7 \\
\hline & & $45-54$ & 10.2 & 2.8 & 19.6 & 117.3 \\
\hline & & $55-64$ & 24.7 & 6.8 & 47.3 & 284.0 \\
\hline & & $65-74$ & 67.4 & 18.5 & 129.2 & 775.0 \\
\hline & & $75-84$ & 255.1 & 69.8 & 488.9 & 2933.4 \\
\hline & & $\geq 85$ & 1053.4 & 288.4 & 2018.8 & 12113.0 \\
\hline & & Total & 51.3 & 14.1 & 98.7 & 592.2 \\
\hline \multirow{10}{*}{$\begin{array}{l}\text { Sudden cardiac } \\
\text { death }^{1}\end{array}$} & \multirow{10}{*}{ All } & $<1$ & 11.2 & 3.1 & 21.5 & 128.8 \\
\hline & & $1-4$ & 2.2 & 0.6 & 4.2 & 25.3 \\
\hline & & $5-9$ & 1.2 & 0.3 & 2.3 & 13.8 \\
\hline & & $10-14$ & 1.2 & 0.3 & 2.3 & 13.8 \\
\hline & & $15-19$ & 2 & 0.6 & 3.8 & 23.0 \\
\hline & & $20-24$ & 3.2 & 0.9 & 6.1 & 36.8 \\
\hline & & $25-29$ & 5.4 & 1.6 & 10.4 & 62.1 \\
\hline & & $30-34$ & 8 & 2.2 & 15.3 & 92.0 \\
\hline & & $35-39$ & 13.3 & 3.6 & 25.6 & 152.9 \\
\hline & & $40-44$ & 20.9 & 5.7 & 40.1 & 240.3 \\
\hline
\end{tabular}




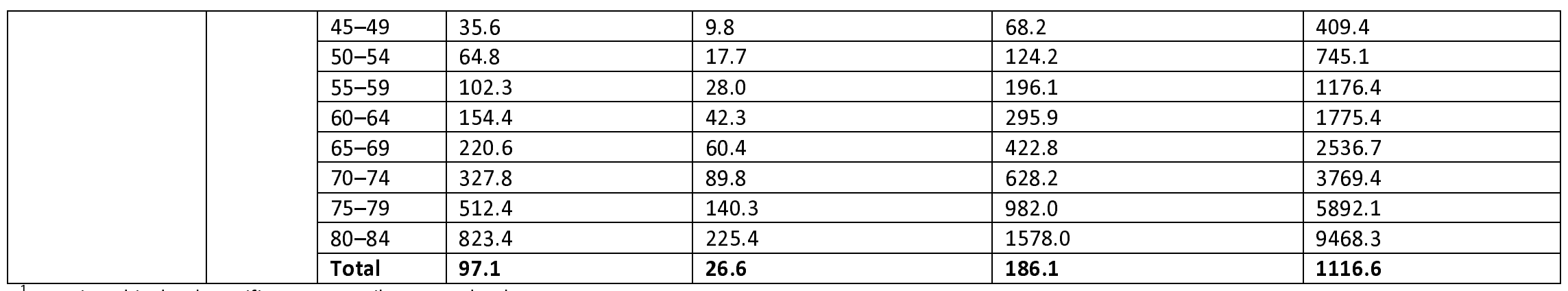

${ }^{1}$ mentioned in death certificate as contributory to death 
medRxiv preprint doi: https://doi.org/10.1101/2021.08.31.21262919; this version posted September 5, 2021. The copyright holder for this preprint

(which was not certified by peer review) is the author/funder, who has granted medRxiv a license to display the preprint in perpetuity.

This article is a US Government work. It is not subject to copyright under 17 USC 105 and is also made available for use under a CCO license.

\section{References}

1. World Health Organization. WHO Director-General's opening remarks at the media briefing on COVID-19 2021. Available at: https://www.who.int/director-general/speeches/detail/who-director-general-s-openingremarks-at-the-media-briefing-on-covid-19---11-march-2020. Accessed July 20, 2021

2. Centers for Disease Control and Prevention. COVID data tracker 2021. Available at: https://covid.cdc.gov/covid-data-tracker/\#datatracker-home Accessed July 20, 2021

3. Thompson MG, Burgess JL, Naleway AL, et al. Interim estimates of vaccine effectiveness of BNT162b2 and mRNA-1273 COVID-19 vaccines in preventing SARS-CoV-2 infection among health care personnel, first responders, and other essential and frontline workers-eight US locations, December 2020-March 2021. MMWR Morb Mortal Wkly Rep 2021;70(13)495-500.

4. Swift MD, Breeher LE, Tande AJ, et al. Effectiveness of mRNA COVID-19 vaccines against SARS-CoV-2 infection in a cohort of healthcare personnel. Clinical Infectious Diseases. 2021.

5. Haas EJ, Angulo FJ, McLaughlin JM, et al. Impact and effectiveness of mRNA BNT162b2 vaccine against SARSCoV-2 infections and COVID-19 cases, hospitalisations, and deaths following a nationwide vaccination campaign in Israel: an observational study using national surveillance data. Lancet 2021;397(10287):1819-1829.

6. Lurie N, Saville M, Hatchett R, Halton J. Developing Covid-19 vaccines at pandemic speed. NEJM 2020;382:1969-1973.

7. Centers for Disease Prevention and Control. COVID-19 vaccination program operational guidance 2021. Available at: https://www.cdc.gov/vaccines/covid-19/covid19-vaccination-guidance.html. Accessed July 20, 2021

8. Daly M, Jones A, Robinson E. Public trust and willingness to vaccinate against COVID-19 in the US from October 14, 2020, to March 29, 2021. JAMA 2021;325(23):2397-2399.

9. Gee J, Marquez P, Su J. et al. First month of COVID-19 vaccine safety monitoring-United States, December 14, 2020-January 13, 2021. MMWR Morb Mortal Wkly Rep 2021;70(8):283-288. 
medRxiv preprint doi: https://doi.org/10.1101/2021.08.31.21262919; this version posted September 5, 2021. The copyright holder for this preprint (which was not certified by peer review) is the author/funder, who has granted medRxiv a license to display the preprint in perpetuity. This article is a US Government work. It is not subject to copyright under 17 USC 105 and is also made available for use under a CCO license.

10. CDC COVID-19 Response Team; Food and Drug Administration. Allergic reactions including anaphylaxis after receipt of the first dose of Pfizer-BioNTech COVID-19 vaccine-United States, December 14-23, 2020. MMWR Morb Mortal Wkly Rep 2021;70(2):46-51.

11. Rosenblum HG, Hadler SC, Moulia D, et al. Use of COVID-19 vaccines after reports of adverse events among adult recipients of Janssen (Johnson \& Johnson) and mRNA COVID-19 vaccines (Pfizer-BioNTech and Moderna): update from the Advisory Committee on Immunization Practices-United States, July 2021. MMWR Morb Mortal Wkly Rep 2021;70(32):1094-1099

12. Black S, Eskola J, Siegrist C, et al. Importance of background rates of disease in assessment of vaccine safety during mass immunisation with pandemic H1N1 influenza vaccines. Lancet. 2009;374:2115-2122.

13. Gubernot D, Jazwa A, Niu M, et al. US Population-Based background incidence rates of medical conditions for use in safety assessment of COVID-19 vaccines. Vaccine. 2021;39(28):3666-3677.

14. Centers for Disease Control and Prevention. Vital statistics online data portal 2020. Available at:

https://www.cdc.gov/nchs/data access/vitalstatsonline.htm. Accessed July 26, 2021.

15. Virani SS, Alonso A, Benjamin EJ, et al. Heart disease and stroke statistics-2020 update: a report from the American Heart Association. Circulation 2020;141:e139-e596.

16. Health Resources and Services Administration. Vaccine injury table. Available at:

https://www.hrsa.gov/sites/default/files/vaccinecompensation/vaccineinjurytable.pdf Accessed July 26, 2021.

17. Baxter R, Bakshi N, Fireman B, et al. Lack of association of Guillain-Barré syndrome with vaccinations. Clin Infect Dis 2013;57:197-204.

18. Beghi E, Kurland LT, Mulder DW, Wiederholt WC. Guillain-Barré syndrome: clinicoepidemiologic features and effect of influenza vaccine. Arch Neurol 1985;42:1053-1057.

19. Shui IM, Rett MD, Weintraub E, et al. Guillain-Barré syndrome incidence in a large United States cohort (2000-2009). Neuroepidemiology 2012;39:109-115.

20. Wise ME, Viray M, Sejvar JJ, et al. Guillain-Barré syndrome during the 2009-2010 H1N1 influenza vaccination campaign: population-based surveillance among 45 million Americans. Am J Epidemiol 2012;175:1110-1119. 
medRxiv preprint doi: https://doi.org/10.1101/2021.08.31.21262919; this version posted September 5, 2021. The copyright holder for this preprint (which was not certified by peer review) is the author/funder, who has granted medRxiv a license to display the preprint in perpetuity. This article is a US Government work. It is not subject to copyright under 17 USC 105 and is also made available for use under a CCO license.

21. Klein NP, Ray P, Carpenter D, et al. Rates of autoimmune diseases in Kaiser Permanente for use in vaccine adverse event safety studies. Vaccine 2010;28:1062-1068.

22. Alshekhlee A, Hussain Z, Sultan B, Katirji B. Guillain-Barré syndrome: incidence and mortality rates in US hospitals. Neurology 2008;70:1608-1613.

23. Langer-Gould A, Brara SM, Beaber BE, Zhang JL. Incidence of multiple sclerosis in multiple racial and ethnic groups. Neurology 2013;80:1734-1739.

24. Mayr WT, Pittock SJ, McClelland RL, Jorgensen NW, Noseworthy JH, Rodriguez M. Incidence and prevalence of multiple sclerosis in Olmsted County, Minnesota, 1985-2000. Neurology 2003;61:1373-1377.

25. Jeffery DR, Mandler RN, Davis LE. Transverse myelitis: retrospective analysis of 33 cases, with differentiation of cases associated with multiple sclerosis and parainfectious events. Arch Neurol 1993;50:532-535.

26. Hassan MB, Stern C, Flanagan EP, et al. Population-Based Incidence of Optic Neuritis in the Era of Aquaporin4 and Myelin Oligodendrocyte Glycoprotein Antibodies. Am J Ophthalmol 2020;220:110-114.

27. Rodriguez M, Siva A, Cross S, O’Brien P, Kurland LT. Optic neuritis - a population-based study in Olmstead County, Minnesota. Neurology 1995;45(2):244-250.

28. Bhatt P, Bray L, Raju S, et al. Temporal trends of pediatric hospitalizations with acute disseminated encephalomyelitis in the United States: an analysis from 2006 to 2014 using national inpatient sample. J Pediatr 2019;206:26-32.

29. Leake JA, Albani S, Kao AS, et al. Acute disseminated encephalomyelitis in childhood: epidemiologic, clinical and laboratory features. Pediatr Infect Dis J. 2004;23:756-764.

30. Nicolosi A, Hauser WA, Beghi E, Kurland LT. Epidemiology of central nervous system infections in Olmsted County, Minnesota, 1950-1981. J Infect Dis 1986;154:399-408.

31. Hauser WA, Annegers JF, Kurland LT. Incidence of epilepsy and unprovoked seizures in Rochester, Minnesota: 1935-1984. Epilepsia. 1993;34:453-458.

32. Annegers JF, Dubinsky S, Coan SP, Newmark ME, Roht L. The incidence of epilepsy and unprovoked seizures in multiethnic, urban health maintenance organizations. Epilepsia. 1999;40:502-506. 
medRxiv preprint doi: https://doi.org/10.1101/2021.08.31.21262919; this version posted September 5, 2021. The copyright holder for this preprint (which was not certified by peer review) is the author/funder, who has granted medRxiv a license to display the preprint in perpetuity. This article is a US Government work. It is not subject to copyright under 17 USC 105 and is also made available for use under a CCO license.

33. Koton S, Sang Y, Schneider AL, Rosamond WD, Gottesman RF, Coresh J. Trends in stroke incidence rates in older us adults: an update from the atherosclerosis risk in communities (ARIC) cohort study. JAMA Neurology. 2020;77:109-113.

34. Silber MH, Krahn LE, Olson EJ, Pankratz VS. The epidemiology of narcolepsy in Olmsted County, Minnesota: a population-based study. Sleep. 2002;25:197-202.

35. Kumar N, Pandey A, Jain P, Garg N. Acute pericarditis-associated hospitalization in the USA: a nationwide analysis, 2003-2012. Cardiology. 2016;135:27-35.

36. Lin AH, Phan H, Barthel RV, et al. Myopericarditis and pericarditis in the deployed military member: a retrospective series. Mil Med 2013;178:18-20.

37. Huang W, Goldberg RJ, Anderson FA, Kiefe Cl, Spencer FA. Secular trends in occurrence of acute venous thromboembolism: the Worcester VTE study (1985-2009). Am J Med 2014;127:829-839. e825.

38. Silverstein MD, Heit JA, Mohr DN, Petterson TM, O'Fallon WM, Melton L. Trends in the incidence of deep vein thrombosis and pulmonary embolism: a 25-year population-based study. Arch Intern Med 1998;158:585593.

39. Rossen LM, Ahrens KA, Branum AM. Trends in risk of pregnancy loss among US women, 1990-2011. Paediatr Perinat Epidemiol 2018;32:19-29.

40. Zinaman MJ, Clegg ED, Brown CC, O’Connor J, Selevan SG. Estimates of human fertility and pregnancy loss. Fertil Steril 1996;65:503-509.

41. Ventura SJ, Curtin SC, Abma JC, Henshaw SK. Estimated pregnancy rates and rates of pregnancy outcomes for the United States, 1990-2008. Natl Vital Stat Rep 2012;60:1-21.

42. Wilcox AJ, Weinberg CR, O'Connor JF, et al. Incidence of early loss of pregnancy. NEJM. 1988;319:189-194. 43. MacDorman MF, Gregory EC. Fetal and perinatal mortality: United States, 2013 Natl Vital Stat Rep $2015 ; 64: 1-24$.

44. Hoyert DL, Gregory EC. Cause-of-death data from the fetal death file, 2015-2017. Natl Vital Stat Rep 2020 69(4):1-20. 
medRxiv preprint doi: https://doi.org/10.1101/2021.08.31.21262919; this version posted September 5, 2021. The copyright holder for this preprint (which was not certified by peer review) is the author/funder, who has granted medRxiv a license to display the preprint in perpetuity.

This article is a US Government work. It is not subject to copyright under 17 USC 105 and is also made available for use under a CCO license.

45. Panagiotakopoulos L, McCarthy NL, Tepper NK, et al. Evaluating the association of stillbirths after maternal vaccination in the Vaccine Safety Datalink. Obstet Gynecol 2020;136:1086-1094.

46. McNicholas A, Galloway Y, Stehr-Green P, et al. Post-marketing safety monitoring of a new group B meningococcal vaccine in New Zealand, 2004-2006. Hum Vaccin 2007;3:196-204.

47. Kokia ES, Silverman BG, Green M, Kedem H, Guindy M, Shemer J. Deaths following influenza vaccinationbackground mortality or causal connection? Vaccine. 2007;25:8557-8561. 